\title{
Application of Sulfentrazone in Stages of Germination of IAC 90 Cassava Cuttings in Clay SoIls and Sandy ${ }^{1}$
}

\author{
Aplicação do Sulfentrazone em Estádios de Germinação de Manivas da Mandioca IAC 90 em \\ Solo Argiloso e Arenoso
}

\author{
ZIMMER, J.S. ${ }^{2}$, FERREIRA, S.D. ${ }^{2}$, RAMELLA, J.R. ${ }^{2}$, RODRIGUES-COSTA, A.C.P. ${ }^{3}$, and \\ COSTA, N.V. ${ }^{2}$
}

\begin{abstract}
Weeds interfere dramatically in the productive potential of cassava; however, information regarding herbicides that are selective to crops is still scarce. Thus, the aim in this study was to assess the initial growth of IAC 90 cassava plants after the application of sulfentrazone at different stages of germination of cassava in clayey and sandy soils. Three experiments were simultaneously deployed: the first experiment consisted in the application of sulfentrazone in the non-germinated stage of cassava cuttings; the second one in the stage of germinated cassavas cuttings $(0.9 \mathrm{~cm}$ shoots); and the third one in applications in the stage of cassava cuttings with buds emerging $(6.5 \mathrm{~cm}$ shoots and emerging from the soil). For each experiment the experimental design in randomized blocks was used in the $2 \times 5$ factorial arrangement with four replications. The factors were composed of two soils (sandy and clayey) and five doses of sulfentrazone $\left(0,250,500,750\right.$ and 1,000 $\mathrm{g} \mathrm{ha}^{-1}$ ). It was found that depending on the herbicide dose, development stage of the buds of cassava cuttings and the type of soil, damage can occur in the initial development of the IAC 90 cassava plants. The greatest potential of sulfentrazone selectivity has occurred in applications in the nongerminated cassava cuttings stage and in doses lower than $500 \mathrm{~g} \mathrm{ha}^{-1}$ in the clayey soil.
\end{abstract}

Keywords: herbicide, Manihot esculenta, protox inhibitor, selectivity.

\begin{abstract}
RESUMO - As plantas daninhas interferem drasticamente no potencial produtivo da mandioca, entretanto, ainda são escassas informações referentes a herbicidas seletivos à cultura. Dessa forma, objetivou-se neste trabalho avaliar o crescimento inicial de plantas de mandioca IAC 90 após a aplicação do sulfentrazone em diferentes estádios de germinação da maniva em solo argiloso e arenoso. Foram implantados três experimentos simultaneamente: o primeiro experimento consistiu na aplicação do sulfentrazone no estádio de maniva não germinada; o segundo, no estádio de maniva germinada (brotos com 0,9 cm); e o terceiro, em aplicações no estádio de manivas com gemas emergidas (brotos com 6,5 cm e emergidos do solo). Para cada experimento, foi adotado o delineamento experimental em blocos casualizados, no esquema fatorial $2 \times 5$, com quatro repetições. Os fatores foram compostos por dois solos (arenoso e argiloso) e cinco doses do sulfentrazone (0, 250, 500, 750 e $\left.1.000 \mathrm{~g} \mathrm{ha}^{-1}\right)$. Concluiu-se que, dependendo da dose do herbicida, do estádio de desenvolvimento das gemas da maniva e do tipo de solo, podem ocorrer danos no desenvolvimento inicial das plantas de mandioca IAC 90. O maior potencial de seletividade do sulfentrazone ocorreu nas aplicações no estádio de maniva não germinada e em doses inferiores a $500 \mathrm{~g}$ ha $^{-1}$ no solo argiloso.
\end{abstract}

Palavras-chave: herbicida, Manihot esculenta, inibidor da protox, seletividade.

1 Recebido para publicação em 11.2.2014 e aprovado em 6.2.2015.

2 Universidade Estadual do Oeste do Paraná, Marechal Cândido Rondon-PR, Brasil, <jhonata_zimmer@hotmail.com>; ${ }^{3}$ Universidade Estadual de Maringá, Umuarama-PR, Brasil. 


\section{INTRODUCTION}

Cassava (Manihot esculenta) can be grown throughout the country due to its adaptation to different conditions of climate and soil, being an important source of human and animal food (Viana et al., 2001).

In Brazil, the State of Paraná stands out among the major cassava growers. Its acreage is around 175.7 thousand ha ${ }^{-1}$, with a yield of 3.9 million tons of roots, 2012/2013 harvest, with an average yield of $22.2 \mathrm{t} \mathrm{ha}^{-1}$, being $35.6 \%$ higher than the national average yield (CONAB, 2013; IBGE, 2013). However, most of the Paraná cassava yield is for the starch and flour industry.

The cassava crop has a slow initial growth and a small shading capacity, which delays the ground cover and provides different emergency flows of weeds during part of its cycle (Lorenzi \& Dias, 1993). Whereas the cassava cycle can reach up to two years, the management problem of weeds becomes an important factor because it may require several management interventions until harvest (Alabi et al., 2001; Oliveira Jr. et al., 2001).

The interference caused by weeds in crop can provide a reduction of up to $90 \%$ in the yield of roots (Peressin et al., 1998; Johanns \& Contiero, 2006). However, in studies carried out by Albuquerque et al. (2008), in the Brazilian municipality of Viçosa, MG, yield losses of cassava roots without weed control have reached $100 \%$.

Thus, chemical management has been suggested as the best alternative, because of the high cost and low yield of manual or mechanical weeding (Alabi et al., 2004; Silveira et al., 2012).

It is noteworthy that in Brazil only herbicides ametryn + clomazone, clethodim, clomazone, isoxaflutole and metribuzin are registered for the cassava crop (Rodrigues and Almeida, 2011). However, in areas of cassava growers in Western Paraná, sulfentrazone has proved to be selective, especially when applied to a clayey soil and before the sprouting of cassava cuttings (personal communication), demonstrating a potential to be included in the management programs of weeds of this crop.

Planta Daninha, Viçosa-MG, v. 33, n. 2, p. 305-314, 2015
Sulfentrazone inhibits protoporphyrinogen oxidase (PROTOX), responsible for the oxidation of protoporphyrinogen to protoporphyrin IX, in the biosynthesis of chlorophyll. It belongs to the chemical group triazolinones and is suitable for applications in preemergence or directed spray, which have an efficient control of various weed species, monocotyledonous and dicotyledonous, of the crops of sugarcane, soy, citrus, coffee and eucalyptus, besides its use in non-agricultural areas (industrial areas, patios, fire lines, fences, roads and railways). It has a solubility in water of $490 \mathrm{mg} \mathrm{L}^{-1}$ and a vapor pressure of $1 \times 10^{-9} \mathrm{~mm} \mathrm{Hg}^{-1}$ at $25^{\circ} \mathrm{C}$. In soil, mobility is moderate, of low adsorption with Koc at 43, pKa at 6.56 and Kow at 1.48, being degraded by microbial action in the soil; its half-life is 180 days (Rodrigues \& Almeida, 2011).

The selectivity of the herbicide on the cassava plants may be related to sulfentrazone behavior in different types of soil and in the anatomical and physiological feature of the plant. Its low mobility in soil (koc 43) and its low affinity with lipids (kow 1.48), including of the plant cells (Rodrigues \& Almeida, 2011) somehow still poorly elucidated, may be responsible for promoting the selectivity observed by growers in the fields.

Preemergent herbicides can be influenced by sorption, leaching and degradation processes and by physical, chemical and biological processes or be absorbed by plants, which are dependent on the type of soil, climate conditions and herbicide characteristics (Alves et al., 2004; Szmigielski et al., 2009) and hence can influence the efficiency in weed control and crop selectivity.

Thus, although sulfentrazone has shown selectivity for cassava crops, there are still only a few studies about its behavior in different types of soils in Western Paraná, such as in sandy soils, since selectivity may be dependent on the herbicide dose and application time due to the development stage of cassava cuttings buds during the emergence period after planting.

Therefore, this study aimed to assess the initial growth of IAC 90 cassava plants after application of sulfentrazone in different cassava cuttings germination stages in clayey and sandy soils. 


\section{MATERIALS AND METHODS}

Three experiments were simultaneously deployed, in which the first experiment consisted in the application of sulfentrazone in the non-germinated cassava cutting stage; in the second one, the applications were in the germinated cassava cuttings stage (shoots having $0.9 \mathrm{~cm}$ in length); and in the third one the applications were in the stage of cassava cuttings with buds emerging (shoots being $6.5 \mathrm{~cm}$ long and emerging from the soil).

The experiments were conducted during the October to December 2012 period, in pot conditions, with a capacity of $15 \mathrm{dm}^{-3}$, packed in the field without the use of a controlled environment, with daily irrigation. For implementation of the experiments the IAC 90 cassava cultivar was used. In planting, cassava cuttings $13-15 \mathrm{~cm}$ long were used, and planting depth was $6 \mathrm{~cm}$.

For each experiment, an experimental design in randomized blocks was adopted, in a $2 \times 5$ factorial arrangement, with four replications. The factors were composed of two soils (clayey and sandy) and five doses of sulfentrazone $(0,250,500,750$ and $1,000 \mathrm{~g} \mathrm{ha}^{-1}$ ).

Two types of soil were used for the experiment. The first one was in a clayey soil, collected in the municipality of Marechal Cândido Rondon, PR, classified as Eutrophic Alfisol (PVe) (Embrapa, 2006), with the following characteristics $\mathrm{pH}\left(\mathrm{CaCl}_{2}\right)=5,06$; organic matter $\left(\mathrm{g} \mathrm{dm}^{-3}\right)=10.94 ; \mathrm{P}\left(\mathrm{mg} \mathrm{dm}^{-3}\right)=6.47$; $\mathrm{H}+\mathrm{Al}, \mathrm{K}, \mathrm{Ca}, \mathrm{Mg}, \mathrm{SB}$ and CTC $\left(\mathrm{cmol}_{\mathrm{c}} \mathrm{dm}^{-3}\right)$ $=4.02 ; 0.24 ; 2.97 ; 1.60 ; 4.81 ;$ and 8.83 , respectively; and $\mathrm{V} \%=54.47$. The clay, silt and sand contents were 522.50, 426.74 and $50.76 \mathrm{~g} \mathrm{~kg}^{-1}$, respectively. The second one was a sandy soil, collected in the municipality of Palotina, PR, classified as Eutrustox Rhodic Hapludox (LVef) (Embrapa, 2006), with the following chemical characteristics: $\mathrm{pH}\left(\mathrm{CaCl}_{2}\right)=4.80$; organic matter $\left(\mathrm{g} \mathrm{dm}^{-3}\right)$ $=15.04 ; \mathrm{P}\left(\mathrm{mg} \mathrm{dm}^{-3}\right)=13.16 ; \mathrm{H}+\mathrm{Al}, \mathrm{K}, \mathrm{Ca}, \mathrm{Mg}$, SB and CTC $\left(\mathrm{cmol}_{c} \mathrm{dm}^{-3}\right)=3.21 ; 0.17 ; 1.82$; $0.49 ; 2.48$; and 5.69 ; respectively; and $\mathrm{V} \%=43.59$. The clay, silt and sand contents were $182.50,88.69$ and $728.80 \mathrm{~g} \mathrm{~kg}^{-1}$, respectively.
For applying sulfentrazone, a backpack sprayer was used, pressurized with $\mathrm{CO}_{2}$ and equipped with a bar of four nozzles spaced $0.5 \mathrm{~m}$ between them, using a fan type tips

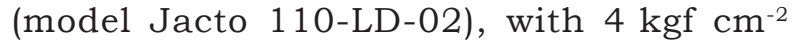
pressure and $200 \mathrm{~L} \mathrm{ha}^{-1}$ spray volume, with moist soil in the application times.

In the first experiment, the application was made in the stage of non-germinated cassava cuttings, soon soon after planting $(10 / 08 / 12)$, starting at 17:40 and ending at $17: 53$, temperature around $32.5{ }^{\circ} \mathrm{C}$, relative humidity $50 \%$ and winds of $2.2 \mathrm{~km} \mathrm{~h}^{-1}$. In the second experiment, the application was performed in the stage of germinated cassava cutting, on the ninth day after planting $(10 / 17 / 12)$, beginning at 18:05 and ending at $18 \mathrm{~h} 18$, with temperature around $23.9^{\circ} \mathrm{C}$, relative humidity $46 \%$ and winds of $2.1 \mathrm{~km} \mathrm{~h}^{-}$ ${ }^{1}$. In the third experiment, the application was done in the stage of cassava cuttings with buds emerged, at 14 days after planting $(10 / 22 / 12)$, beginning at 17:50 and ending at 18:03, temperature around $27^{\circ} \mathrm{C}$, relative humidity $45 \%$ and winds of $3.4 \mathrm{~km} \mathrm{~h}^{-1}$.

The phytotoxicity was assessed at 17,24 , $31,38,45,52$ and 59 days after application (DAA) for the non-germinated cassava cutting; at $8,15,22,29,36,43$ and 50 DAA for the germinated cassava cutting; and at $3,10,17$, 24, 31, 38 and 45 DAA for cassava cuttings with buds emerged. Phytotoxicity was visually assessed according to a rating percentage scale, where 0 corresponded to no intoxication and 100 corresponded to the death of the plants, taking into account the inhibition of growth, quantity and uniformity of injuries, leaf abscission and regrowth capacity of the plants (SBCPD, 1995).

At 63 DAA for non-germinated cassava cuttings, at 54 DAA for germinated cassava cuttings and at 49 DAA for cassava cuttings with buds emerged, the potted plants were collected and the leaf area $\left(\mathrm{cm}^{2}\right)$ was assessed with the aid of device LI-3100C Portable Leaf Area Meter and the plant total dry matter, and the collected material was packed in paper bags and taken to the oven of forced air circulation at $65^{\circ} \mathrm{C}$ for 72 hours; subsequently, they were weighed on a precision weighing balance to determine the mass in grams.

Planta Daninha, Viçosa-MG, v. 33, n. 2, p. 305-314, 2015 
In the same period, the assessment of the $\mathrm{CO}_{2}$ flow rate $\left(\mu \mathrm{mol} \mathrm{CO} \mathrm{C}^{-2} \mathrm{~s}^{-1}\right)$ took place by reading with equipment IRGA LI-6400XT (Licor Inc. Lincoln, NE), which was taken in the morning between 9 and 12 hours on a sunny day, according to the methodology adapted and proposed by Ferraz et al. (2012), as well as of the fully developed leaves, photosynthetically active and without lesions, located in the middle third of the plants, using a leaf from each plant per pot. The incident light rate at the time of the assessment was $1,500 \pm 5.4$ PAR.

The results of phytotoxicity were applied in surface charts built from multiple regression models, depending on the doses and the assessment period. The leaf area data, total dry matter and net photosynthesis rate were subjected to analysis of variance by $\mathrm{F}$ test at $5 \%$ probability. The data were submitted to regression analysis, and the equations were chosen considering the significance of the $F$ test, normality and high coefficient of determination $\left(R^{2}\right)$.

\section{RESULTS AND DISCUSSION}

Sulfentrazone caused phytotoxicity symptoms in mild to severe levels in the IAC 90 cassava plants in both soils assessed (Figures 1 and 2). In the clayey soil, there was an increase of symptoms as the dose of the herbicide increased in all stages of the application (Figure 1).

In the stage of non-germinated cassava cutting, symptoms considered mild $(\leq 20 \%)$ were observed for doses below $250 \mathrm{~g} \mathrm{ha}^{-1}$, whereas for higher doses the symptoms ranged from 40 to $60 \%$ of phytotoxicity at 59 DAA (Figure 1A). The use of above $250 \mathrm{~g} \mathrm{ha}^{-1}$ doses of sulfentrazone in the applications in the stages of germinated cassava and cassava cuttings with buds emerged caused phytotoxicity symptoms considered moderate to severe (40 to $100 \%$ ) at 50 and $45 \mathrm{DAA}$, respectively (Figures $1 \mathrm{~B}$ and $1 \mathrm{C}$ ).

In the sandy soil, for the stage of nongerminated cassava cutting, the phytotoxicity symptoms ranged from mild to severe (40 to $80 \%$ ) from the dosage of $250 \mathrm{~g} \mathrm{ha}^{-1}$ at 59 DAA (Figure 2A). For the stages of germinated cassava cutting and with emerged buds, symptoms over $40 \%$ from $500 \mathrm{~g} \mathrm{ha}^{-1}$ of sulfentrazone were observed, while there were severe symptoms in the applications of higher doses at 50 and 45 DAA, respectively (Figure 2B, C).

In general, the phytotoxicity symptoms caused by sulfentrazone in IAC 90 cassava plants were characterized by intense chlorosis mainly in young leaves, followed by further corrugation and formation of internerval chlorosis on the leaf surface, sometimes resembling a mosaic, besides supergermination occurring along the stem of the plant. As for the doses in excess of $500 \mathrm{~g} \mathrm{ha}^{-1}$, drastic reduction in plant growth may occur, especially when applied to sandy soil.

Comparing the two types of soil, it was observed that there was a higher tolerance of cassava plants to sulfentrazone when applied in the stage of non-germinated cassava cutting and in clayey soil conditions. It is noteworthy that the cassava cuttings have a relatively long period of buds emergence (15 to 20 days after planting); therefore, the application of sulfentrazone near the buds emergence can be a limiting factor to selectivity, because the buds of the cassava cuttings are the preferred point of herbicide absorption.

In Table 1 are the summaries of the variance analysis of the experiments, for parameters leaf area, dry matter and photosynthesis of the IAC 90 cassava plants after application of sulfentrazone. It was found that there was an interaction between the type of soil and herbicide doses only for the parameter dry matter in the application stage of non-germinated cassava cuttings (Experiment 1). In the other application stages there was significance only for the dose factor.

In Figure 3 it is possible to observe the results of leaf area, dry matter and photosynthesis of the IAC 90 cassava plants in the stage of non-germinated cassava cuttings at 63 DAA. It has been found that minor reductions $(<4 \%)$ of the leaf area were obtained in the applications up to $500 \mathrm{~g} \mathrm{ha}^{-1}$ of sulfentrazone in the clayey soil. In the sandy soil, the dose of $250 \mathrm{~g} \mathrm{ha}^{-1}$ induced a reduction 
of $29.9 \%$, similar to that obtained for the highest dose applied to the clayey soil $(35.7 \%)$ compared to the non-applied control (Figure 3A).

$\hat{y}=56.7364+\left(0,1041^{\star}\right.$ Dose $)-\left(1.7725^{\star} D A A\right)-\left(3.8122 E-05^{\star} D^{2} e^{2}\right)+\left(0.0287^{\star} D A A^{2}\right) ; R^{2}=0.88^{\star \star}$

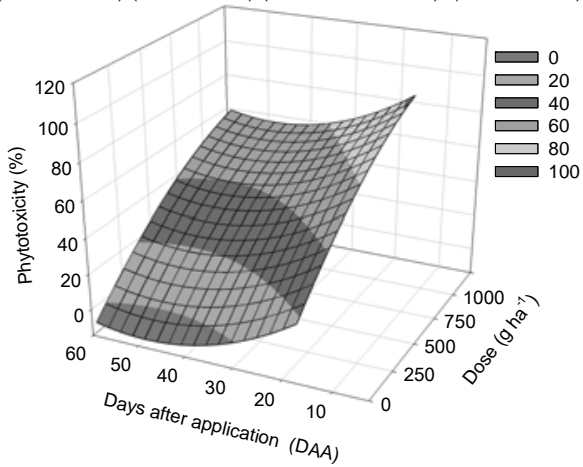

(A)

$\hat{y}=22.4938+\left(0.1345^{*}\right.$ Dose $)-\left(1.7^{*}\right.$ DAA $)-\left(4.7442 E-05^{*}\right.$ Dose $\left.^{2}\right)+\left(0.026^{*} D_{A A}^{2}\right) ; R^{2}=0.90^{* *}$

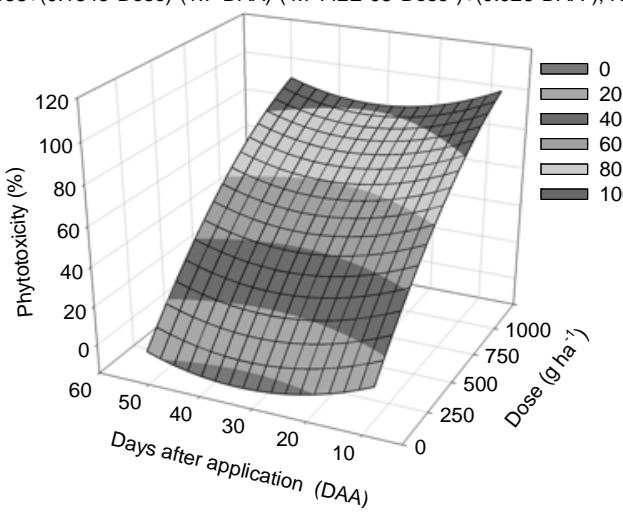

(B)

$\hat{y}=13.6204+(0.2224 *$ Dose $)-\left(0.8533^{*}\right.$ DAA $)-\left(0.0001 *\right.$ Dose $\left.^{2}\right)+\left(0.0084^{*} D A A^{2}\right) ; R^{2}=0.93^{* *}$

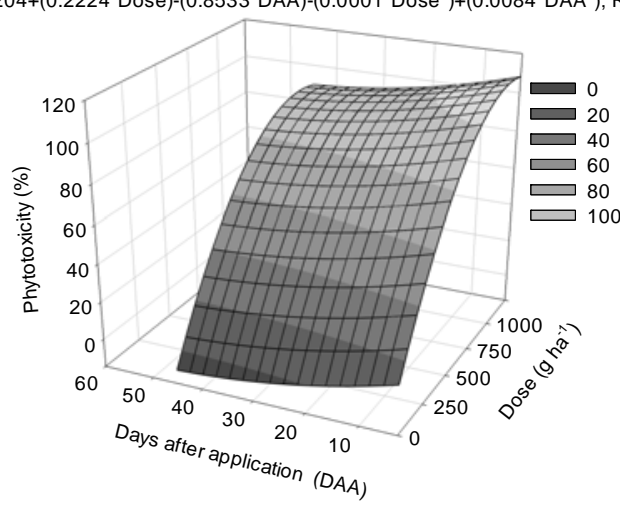

(C)

\footnotetext{
** Significant at $1 \%$ of probability by the $\mathrm{F}$ test.
}

Figure 1 - Phytotoxicity percentage in IAC 90 cassava plant after application of sulfentrazone at different stages of germination of cassava cuttings in clayey soil. (A) nongerminated cassava cutting, (B) germinated cassava cutting and $(\mathrm{C})$ cassava cutting with buds emerged from the soil.
As for the dry matter data, there was a behavior similar to those obtained from the leaf area, but at the dose of $500 \mathrm{~g} \mathrm{ha}^{-1}$ of the sulfentrazone in the clayey soil there was a

$\hat{y}=92.3641+(0,1587 *$ Dose $)-(4.604 * D A A)-\left(8.785 E-05^{\star}\right.$ Dose $\left.^{2}\right)+\left(0.0508^{\star} D A A^{2}\right) ; R^{2}=0.89 * \star$

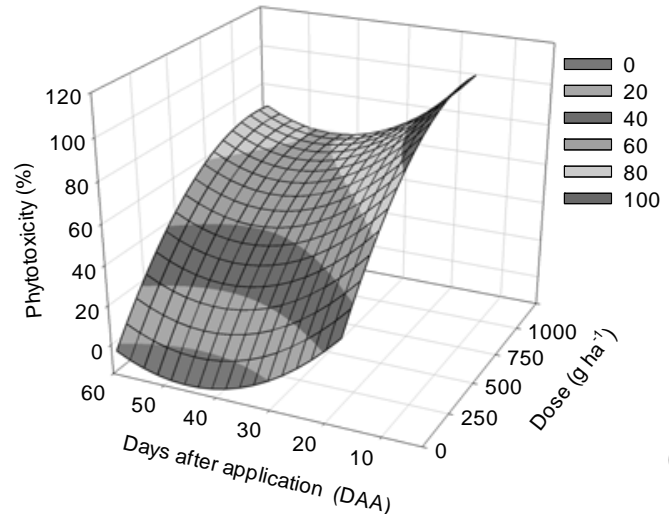

(A)

$\hat{y}=33.9804+\left(0.2131^{*}\right.$ Dose $)-(2.6254 * D A A)-\left(0.0001^{*}\right.$ Dose $\left.^{2}\right)+\left(0.0369^{*} D_{A A}{ }^{2}\right) ; R^{2}=0.91^{\star *}$

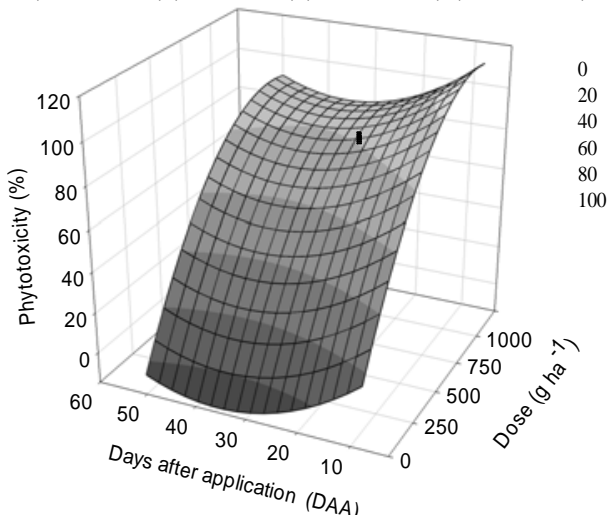

(B)

$\hat{y}=11.5893+(0.2702 *$ Dose $)-(0.2468 * D A A)-\left(0.0002 * D^{*} e^{2}\right)-\left(0.0036 * D^{*} A^{2}\right) ; R^{2}=0.91$ **

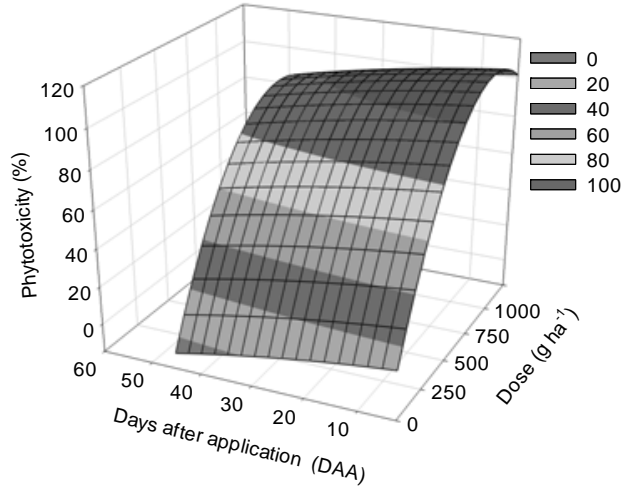

(C)

Figure 2 - Phytotoxicity percentage of IAC 90 cassava plants after application of sulfentrazone at different stages of germination of cassava cuttings in sandy soil. (A) nongerminated cassava cutting, (B) germinated cassava cutting and (C) cassava cutting with buds emerged from the soil. 
Table 1 - Summary of the experiments analyzes of variance for parameters leaf area, dry matter and IAC 90 cassava plants photosynthesis

\begin{tabular}{|c|c|c|c|}
\hline \multirow{2}{*}{ Sources of variation } & Leaf area & Dry matter & Photosynthesis \\
\hline & $\left(\mathrm{cm}^{2}\right)$ & (g per plant) & $\left(\mu \mathrm{mol} \mathrm{CO} \mathrm{Cm}^{-2}\right)$ \\
\hline \multicolumn{4}{|c|}{ Experiment 1 - Non-germinated cassava cutting } \\
\hline Soil (S) & $19.340 * *$ & $18.977^{* *}$ & $0.246^{\mathrm{ns}}$ \\
\hline Doses (D) & $3.316^{*}$ & $10.360 * *$ & $4.746 * *$ \\
\hline$(\mathrm{S}) \times(\mathrm{D})$ & $1.737^{\mathrm{ns}}$ & $3.106^{*}$ & $1.386^{\mathrm{ns}}$ \\
\hline Block & $0.590^{\mathrm{ns}}$ & $1.694^{\text {ns }}$ & $0.565^{\mathrm{ns}}$ \\
\hline CV (\%) & 39.87 & 36.12 & 33.4 \\
\hline \multicolumn{4}{|c|}{ Experiment 2 - Germinated cassava cutting } \\
\hline Soil (S) & $1.945^{\mathrm{ns}}$ & $2.422^{\text {ns }}$ & $0.005^{\mathrm{ns}}$ \\
\hline Doses (D) & $11.896 * *$ & $13.754^{* *}$ & $10.459 * *$ \\
\hline$(\mathrm{S}) \times(\mathrm{D})$ & $1.402^{\mathrm{ns}}$ & $0.708^{\mathrm{ns}}$ & $0.768^{\mathrm{ns}}$ \\
\hline Block & $1.283^{\mathrm{ns}}$ & $1.784^{\mathrm{ns}}$ & $1.782^{\text {ns }}$ \\
\hline $\mathrm{CV}(\%)$ & 53.34 & 56.97 & 38.07 \\
\hline \multicolumn{4}{|c|}{ Experiment 3 - Cassava cuttings with emerged buds } \\
\hline Soil (S) & $1.083^{\mathrm{ns}}$ & $1.734^{\mathrm{ns}}$ & $0.004^{\mathrm{ns}}$ \\
\hline Doses (D) & $29.918 * *$ & $33.540 * *$ & $10.772^{* *}$ \\
\hline$(\mathrm{S}) \times(\mathrm{D})$ & $0.464^{\mathrm{ns}}$ & $0.601^{\mathrm{ns}}$ & $0.772^{\mathrm{ns}}$ \\
\hline Block & $0.829^{\text {ns }}$ & $0.185^{\mathrm{ns}}$ & $2.006^{\text {ns }}$ \\
\hline $\mathrm{CV}(\%)$ & 59.75 & 58.1 & 49.41 \\
\hline
\end{tabular}

** Significant at $1 \%$ probability by $\mathrm{F}$ test, * significant at $5 \%$ probability by $\mathrm{F}$ test; ns non-significant.

reduction by $11.1 \%$ of the biomass compared to the control. At the same dose in the sandy soil, the reduction was $55.2 \%$ (Figure 3B).

The $\mathrm{CO}_{2}$ flow was not influenced by soil type, and was negatively affected only by doses of 250, 500, 750 and $1,000 \mathrm{~g} \mathrm{ha}^{-1}$ of sulfentrazone around $2.7 ; 12.3 ; 28.8$; and $52.1 \%$, respectively (Table 1 and Figure $3 \mathrm{C}$ ).

In Figure 4 it is possible to see the results for leaf area, dry matter and photosynthesis of the IAC 90 cassava plants in the stage of germinated cassava cuttings at 54 DAA.

It was found that the parameters assessed were not influenced by the soil type (Table 1). However, the plant leaf area was linearly reduced at the rate of $0.5373 \mathrm{~cm}^{2}$ per gram of sulfentrazone (Figure 4A).

Reductions of 35.6 and $24.1 \%$ were observed for the dry matter and photosynthesis data, respectively, compared to the control, from the dose of $250 \mathrm{~g} \mathrm{ha}^{-1}$ of sulfentrazone, intensifying as there was an increase of the herbicide dose (Figure 4B, C).

Likewise, in the stage of application of cassava cuttings with buds emerged at 49 DAA it was possible to see already from the dose of $250 \mathrm{~g} \mathrm{ha}^{-1}$ a reduction around 54, 53 and $8 \%$ of parameters leaf area, dry matter and photosynthesis, respectively (Figure 5).

Sulfentrazone mechanism of action corresponds to the inhibition of the enzyme protoporphyrinogen oxidase (PROTOX). The inhibition of PROTOX causes a reduction in synthesis of the photosynthetic pigments (chlorophyll and carotenoids) and oxidative stress, leading to cell death (Jacobs et al., 1991; Lee et al., 1993; Dayan \& Weete, 1996; Szmigielski et al., 2009).

These effects justify the inhibition of the photosynthetic activity observed in this study. However, the negative effects of cassava plants on photosynthesis can be minimized with sulfentrazone applications $\left(<500 \mathrm{~g} \mathrm{ha}^{-1}\right)$ in 

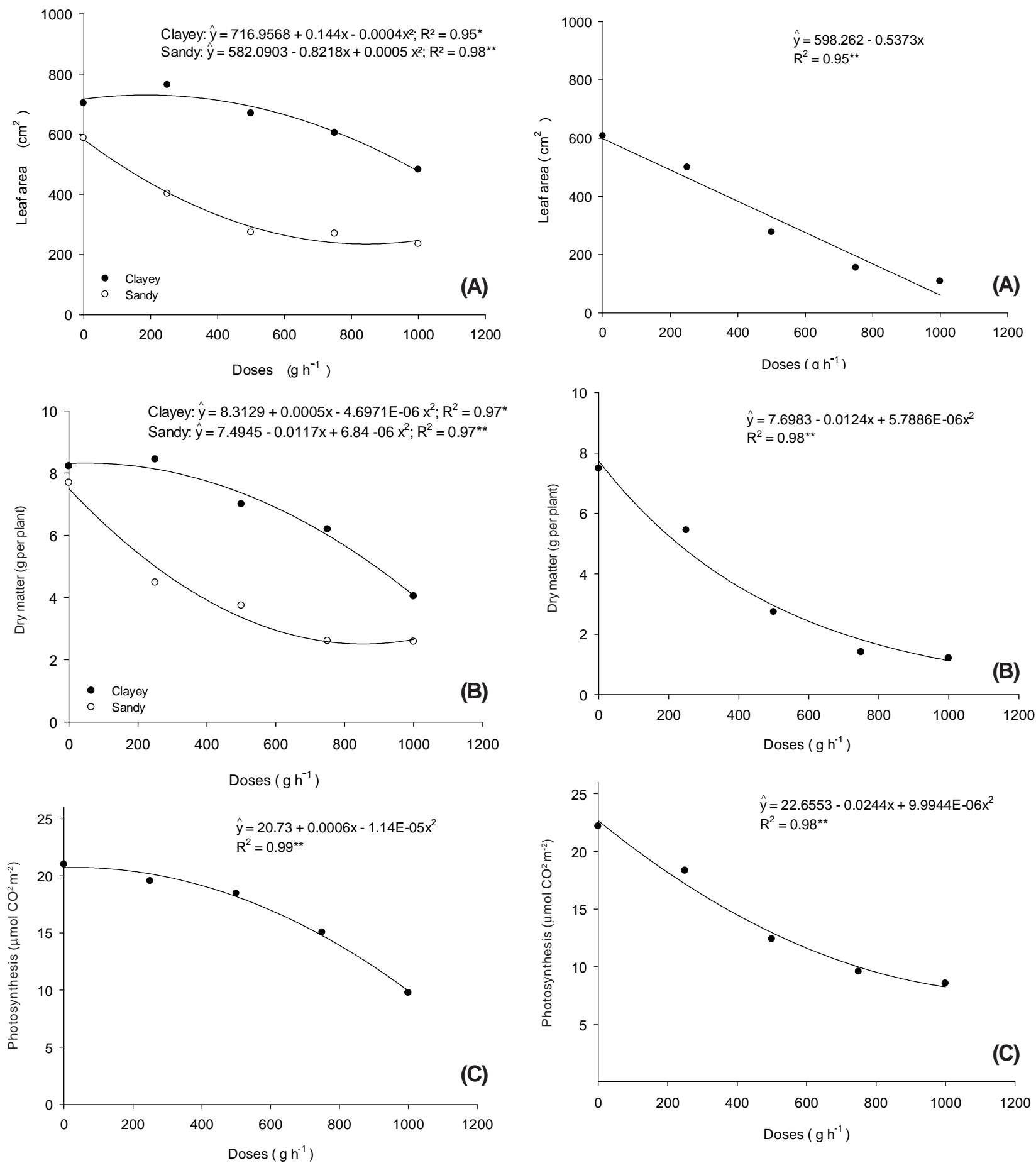

** Significant at $1 \%$ probability and $*$ significant at $5 \%$ probability by $\mathrm{F}$ test.

Figure 3 - Leaf area (A), dry matter (B) and photosynthesis (C) of IAC 90 cassava plants due to the application of sulfentrazone in the stage of non-germinated cassava cuttings at DAA.

Figure 4 - Leaf area (A), dry matter (B) and photosynthesis (C) of IAC 90 cassava plants due to the application of sulfentrazone in the stage of germinated cassava cutting at 54 DAA. 

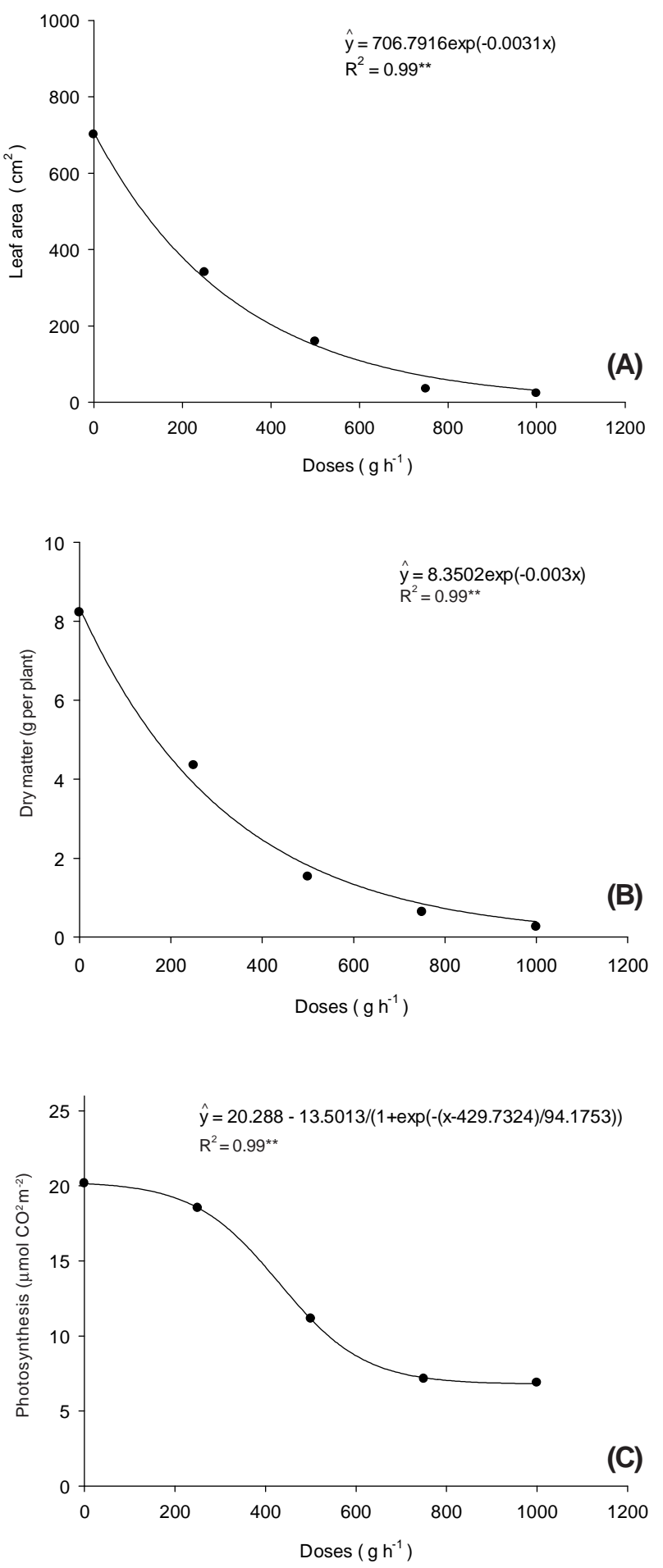

** Significant at $1 \%$ and * significant at $5 \%$ probability by $\mathrm{F}$ test.

Figure 5 - Leaf area (A), dry matter (B) and photosynthesis (C) of IAC 90 cassava plants due to the application of sulfentrazone in the state of cassava cuttings with emerged buds at 49 DAA. preemergence, before the development of buds and roots of cassava (Figure 3C).

Generally, it can be seen that sulfentrazone was more damaging for the IAC 90 cassava plants when applied in the stages of germinated cassava cuttings and with emerged buds, regardless of soil type and the dose administered. As for the stage of non-germinated cassava cutting, there was less damage to the initial development of the plants in the applications of doses between 250 and $500 \mathrm{~g} \mathrm{ha}^{-1}$ of sulfentrazone in the clayey soil.

The greater tolerance of the cassava plants to sulfentrazone applied in the stage of nongerminated cassava cuttings soon after planting can be a result of not having in that period preferred points of herbicide absorption in cassava cuttings, contrary to what happens in applications from the tenth day after planting, in which the development of the roots and the buds of cassavas cuttings seeds start (El-Sharkawy, 2003).

It is noteworthy that sulfentrazone shows greater adsorption in soils with high clay and organic matter content due to its large specific surface and high retention capacity and ion exchanges, compared to sandy textured soils(Reddy \& Locke, 1998; Polubesova et al., 2003). Thus, the physicochemical characteristics of sulfentrazone (water solubility $=490 \mathrm{mg} \mathrm{L}^{-1}$ and low levels of Koc $=43$ and of Kow $=1.48)($ Rodrigues \& Almeida, 2011), indicate a higher mobility of the active ingredient in sandy soils profile in relation to the clayey ones and therefore provide a lower concentration of the active ingredient dissolved in the solution of clayey soils, as well as low uptake by the roots and buds of cassava cuttings in the early developmental stages of the cassava plant.

Oliveira Jr. et al. (2001) have concluded that sulfentrazone (600 $\left.\mathrm{g} \mathrm{ha}^{-1}\right)$ applied in Distrophic Red Oxisol of medium texture $(70 \%$ of sand) and in the no-tillage system has reduced yield by $62.9 \%$ and was not selective to Espeto cassavas cultivar. As for Scariot et al. (2013), they have found that sulfentrazone (600 $\left.\mathrm{g} \mathrm{ha}^{-1}\right)$ and the mixture of clomazone + sulfentrazone $\left(900+500 \mathrm{~g} \mathrm{ha}^{-1}\right)$ have not caused phytotoxicity symptoms and have not 
reduced the yield of Cascuda cassava roots in the applications in clayey soil (55\% of clay), being considered selective.

These results indicate greater selectivity of sulfentrazone to cassava plants grown under conditions of clayey soils, as verified on data obtained from applications in the stages of non-germinated cassava cuttings (Figure 3).

It was concluded that the damage of sulfentrazone in the initial development of the IAC 90 cassava plants depended on dose, the development stage of the cassava cuttings buds and the soil type. However, sulfentrazone has shown higher selectivity potential when applied in the stage of non-germinated cassava cutting and at doses lower than $500 \mathrm{~g} \mathrm{ha}^{-1}$ in clayey soil.

\section{LITERATURE CITED}

ALABI, B. S. et al. Giant sensitive plant interference in cassava. Weed Sci., v. 49, n. 2, p. 171-176, 2001.

ALABI, B. S. et al. Manual control of thorny mimosa (Mimosa invisa) in cassava (Manihot esculenta).

Weed Technol., v. 18, n. 1, p. 77-82, 2004.

ALVES, P. L. C. A.; JÚNIOR, J. M.; FERRAUDO, A. S. Soil attributes and the efficiency of sulfentrazone on control of purple nutsedge (Cyperus rotundus L.). Sci. Agric., v. 61, n. 3, p. 319-325, 2004.

ALBURQUERQUE, J. A. A. et al.. Interferência de plantas daninhas sobre a produtividade da mandioca (Manihot esculenta). Planta Daninha, v. 26, n. 2, p. 279-289. 2008.

COMPANHIA NACIONAL DE ABASTECIMENTO CONAB. Acompanhamento da Safra Brasileira: grãos, nono levantamento, junho 2013. Companhia Nacional de Abastecimento. Brasília, 2013. 30 p. Disponível em: <http:// www.conab.gov.br/OlalaCMS/uploads/arquivos/ 13_06_06_09_09_27_boletim_graos_-_junho_2013.pdf >. Acesso em: 13 jun. 2013.

DAYAN, F. E.; WEETE, J. D. Mechanism of tolerance to a novel phenyl triazolinone herbicide. Plant Physiol., v. 111, n. 2, p. 498-498, 1996.

EL-SHARKAWY, M. A. Cassava biology and physiology. Plant Molec. Biol., v. 53, n. 5, p. 481-501, 2003.

EMPRESA BRASILEIRA DE PESQUISA AGROPECUÁRIA - EMBRAPA. Serviço Nacional de Levantamento e Conservação de Solos. Sistema brasileiro de classificação de solos. Rio de Janeiro: 2006. 412 p.
FERRAZ, R. L. S. et al. Trocas gasosas e eficiência fotossintética em ecótipos de feijoeiro cultivados no semiárido. R. Pesq. Trop., v. 42, p. 181-188, 2012.

\section{INSTITUTO BRASILEIRO DE GEOGRAFIA E} ESTATÍSTICA - IBGE. Levantamento sistemático da produção agrícola: pesquisa mensal de previsão e acompanhamento das safras agrícolas no ano civil, abril de 2013. Rio de Janeiro, v.26 n. 4, p.1-86, 2013. Disponível em: <http://www.ibge.gov.br/home/estatistica/indicadores/ agropecuaria/lspa/lspa_201304.pdf >. Acesso em: 13 jun. 2013.

JACOBS, J. M. et al. Effect of diphenyl ether herbicides on oxidation of protoporphyrinogen to protoporphyrin in organelle and plasma membrane enriched fractions of barley. Plant Physiol., v. 97, n. 1, p. 197-203, 1991.

JOHANNS, O.; CONTIERO, R. L. Efeitos de diferentes períodos de controle e convivência de plantas daninhas com a cultura da mandioca. R. Ci. Agron., v. 37, n. 3, p. 326-331, 2006.

LEE, H. J.; DUKE, S. O.; DUKE, M. V. Cellular localization of protoporphyrinogen-oxidizing activities of etiolated barley (Hordeum vulgare L.) leaves. Plant Physiol., v. 102, n. 3, p. 881-889, 1993.

LORENZI, J. O.; DIAS, C. A. C. Cultura da mandioca. Campinas: Coordenadoria de Assistência Técnica Integral CATI, 1993. 41 p. (Boletim Técnico, 211).

OLIVEIRA JR., R. S. et al. Manejo químico de plantas daninhas em área de plantio direto de mandioca. R. Bras. Herbic., v. 2, n. 3, p. 99-106, 2001.

PERESSIN, V. A. et al. Acúmulo de matéria seca na presença e na ausência de plantas infestantes no cultivo de mandioca SRT 59-branca de Santa Catarina. Bragantia, v. 57, n. 1, p. 1-16, 1998.

POLUBESOVA, T. et al. Sulfentrazone adsorbed on micellemontmorillonite complexes for slow release in soil. J. Agric. Food Chem., v. 51, n. 11, p. 3410-3414, 2003.

REDDY, K. N.; LOCKE, M. A. Sulfentrazone sorption, desorption, and mineralization in soils from two tillage systems. Weed Sci., v. 46, n. 4, p. 494-500, 1998.

RODRIGUES, B. N.; ALMEIDA, F. S. Guia de herbicidas. Londrina: IAPAR, 2011. 697 p.

SCARIOT, C. A. et al. Seletividade e eficiência de herbicidas aplicados em pré-emergência na cultura da mandioca. Pesq. Agropec. Trop., v. 43, n. 3, p. 300-307, 2013.

Planta Daninha, Viçosa-MG, v. 33, n. 2, p. 305-314, 2015 
SILVEIRA, H. et al. Sensibilidade de cultivares de mandioca ao herbicida mesotrione. R. Bras. Herbic., v. 11, n. 1, p. 24-31, 2012.

SOCIEDADE BRASILEIRA DA CIÊNCIA DAS PLANTAS DANINHAS - SBCPD. Procedimentos para instalação, avaliação e análise de experimentos com herbicidas. Londrina: 1995. 42 p.
SZMIGIELSKI, A. M. et al. Development of a laboratory bioassay and effect of soil properties on sulfentrazone phytotoxicity in soil. Weed Technol., v. 23, n. 3, p. 486-491, 2009.

VIANA, A. E. S.; SEDIYAMA, T.; CECON, P. R. Efeito do comprimento e de incisões no córtex da maniva sobre o cultivo da mandioca (Manihot esculenta Crantz). Acta Sci., v. 23, n. 5, p. 1263-1269, 2001. 